Reprod. Nutr. Dévelop., 1986, 26 (2 B), 703-704.

\title{
Protein synthesis in small intestine and liver during postnatal development in the lamb
}

D. ATtAIX, A. MANGHEBATI, M. ARNAL

I.N.R.A. Laboratoire d'étude du métabolisme azoté et C.N.R.S. U.A. 041123 ,

Theix, 63122 Ceyrat, France.

Both the small intestine and liver account for $33 \%$ to $49 \%$ of total protein synthesis in the rat, from 3 to 105 weeks of life (Goldspink and Kelly, 1984; Goldspink et al., 1984). Very little information is available, however, on the earliest stages of postnatal development. We describe here changes in protein synthesis before weaning in the small intestine and liver of one and five-week old lambs. The same large dose method was used for both ages to overcome problems that arise when measuring protein synthesis in these tissues (McNurlan et al., 1979).

Material and methods. Eighteen crossbred male lambs (lle de France $\times$ Romanov-Limousin) were fed a commercial milk replacer ad libitum and separated into 2 groups of 9 animals each which were respectively 1 and 5 weeks old. They received an intravenous injection of a large dose of L-valine $112.8 \mathrm{mmol} / 5 \mathrm{~kg}$ B.W.) in saline combined with $L-\left(3,4, n^{-3} \mathrm{H}\right) \mathrm{Val}$ to provide an injected specific radioactivity (S.R.) of $0.21 \mu \mathrm{Ci} / \mu \mathrm{mol}$. Blood samples were regularly collected until slaughter and plasma was isolated. At both ages, 3 lambs were bled under anaesthesia at 5,13 , or 30 min after ${ }^{3} \mathrm{H}$-Val injection, and samples of duodenum, jejunum, ileum and liver were quickly removed, rinsed with cold saline and frozen in liquid nitrogen. Quantitative separation of free amino acids and proteins was performed using $10 \%$ trichloroacetic acid. Tissue protein content was calculated as $\mathrm{N} \times 6.25$ (Kjeldahl). Valine protein-bound S.R. was calculated from the S.R. of proteins (Packard Tri-carb $460 \mathrm{CD}$ ) and the valine content of mixed tissue proteins. S.R. of the precursor (plasma or tissue free ${ }^{3} \mathrm{H}$-Val) was obtained using a flow detector (Flo-One DR Radiomatic) connected to the column of an automatic amino acid analyser through a 3-way solenoid valve. The fractional rates of protein synthesis ( $\mathrm{Ks}$ in \%/d) were calculated as the slope of the linear regression of $\mathrm{SB}_{(\mathrm{t})}$ on $\mathrm{SA} . \mathrm{t}$ in the equation

$$
100 \cdot \mathrm{SB}_{(\mathrm{t})}=\mathrm{Ks}(\mathrm{SA} \cdot \mathrm{t})+100 \cdot \mathrm{SB}_{(t 0)} \text {, }
$$

i.e. the integrated form of the formula Ks $=(\mathrm{SB} / \mathrm{SA} . \mathrm{t}) \times 100$ (McNurlan et al., 1979), where $t$ is the incorporation time in days, $S A$ is the mean S.R. of free valine between $t_{0}$ and $t$, and $S B$ is the $S$. R. of protein-bound valine. Statistical comparisons of Ks were made by covariance analysis.

Results and discussion. The S.R. of free valine was relatively constant, with a slight but linear decrease between 5 and 30 min after ${ }^{3} \mathrm{H}$-Val injection in both the plasma and tissues. The ratios of free valine S.R. in the plasma and tissue pools, ranging from $78 \%$ to $92 \%$, were at a minimum in the jejunum. 
The changes in S.R. of protein-bound valine were linear with respect to time. Extrapolation of the data to zero time showed positive intercepts, although they were not significantly different from the origin. This, however, had no effect on Ks calculations.

TABLE 1. - Rates of protein synthesis (Ks in \%/d \pm S.D.) in the small intestine and liver of preruminant lambs.

\begin{tabular}{ccccccccc}
\hline $\begin{array}{c}\text { Age } \\
\text { (weeks) }\end{array}$ & \multicolumn{2}{c}{ Duodenum } & \multicolumn{2}{c}{ Jejunum } & \multicolumn{2}{c}{ lleum } & \multicolumn{2}{c}{ Liver } \\
\hline & $K s p$ & $K s t$ & $K s p$ & $K s t$ & $K s p$ & $K s t$ & $K s p$ & $K s t$ \\
\hline 5 & $69 \pm 8^{\text {ad }}$ & $78 \pm 10^{\text {cd }}$ & $68 \pm 8^{\text {ad }}$ & $88 \pm 7^{\text {cd }}$ & $69 \pm 6^{\text {ad }}$ & $82 \pm 4^{\text {cd }}$ & $95 \pm 7^{\text {bd }}$ & $107 \pm 12^{\text {cd }}$ \\
& $66 \pm 2^{\text {ad }}$ & $71 \pm 2^{\text {cd }}$ & $65 \pm 4^{\text {ad }}$ & $78 \pm 5^{\text {cd }}$ & $60 \pm 4^{\text {ad }}$ & $68 \pm 4^{\text {ce }}$ & $58 \pm 4^{\text {ae }}$ & $64 \pm 5^{\text {ce }}$
\end{tabular}

Ks were calculated with the S.R. of free valine in plasma (Ks $p$ ) or in tissues (Ks $t$ ).

$a, b K s p$ values with the same superscript within a line are not significantly different $(P<0.05)$

cKs $t$ values with the same superscript within a line are not significantly different $(P<0.05)$.

d.evalues with the same superscript within a column are not significantly different $(\mathrm{P}<0.05)$.

The fractional rates of protein synthesis (Ks), calculated with the free valine S.R. either in the plasma (Ks p) or in the tissues ( $K s t$ ), are quite similar (table 1). They are in agreement with data obtained in other species (foetuses or young weaned animals) with respect to age differences and nutritional status. Ks were slightly higher in the liver than those measured in the small intestine of 1-week old lambs. No significant differences were observed along the small intestine according to the recent findings of Southon et al. (1985) in jejunal and ileal mucosa of young rats (approximately $180 \mathrm{~g}$ ).

With increasing age, protein synthesis was significantly reduced (- $40 \%)$ in the liver. This is probably related to the decline in ribosomal capacity (i.e. R.N.A./protein) observed in the liver of lambs before weaning (Ferrara and Arnal, unpublished results). In the small intestine, there was a significant reduction of protein synthesis in the ileum with only slight decreases in the duodenum and jejunum. These variations could be related to the decrease in intestinal epithelium cell renewal that we observed during the same period in lambs of identical genotype bred in similar conditions (Attaix and Meslin, 1986).

In conclusion, protein synthesis is high in the small intestine and liver of unweaned lambs. Thus, from the start of the postnatal period, these tissues account for a significant part of total protein synthesis.

Résumé. La synthèse des protéines intestinales et hépatiques a été mesurée chez des agneaux préruminants âgés d'une et de 5 semaines, à l'aide d'une surcharge de $L$ valine et de $\mathrm{L}-\left(3,4, n-{ }^{3} \mathrm{H}\right)$ Val. Les vitesses fractionnaires de synthèse des protéines, élevées à l'âge d'une semaine (68 à $107 \%$ /jour), diminuent significativement avec l'âge dans le foie et plus faiblement dans l'intestin grêle.

Attaix D., Meslin J. C., 1986. Reprod. Nutr. Dévelop., 26, 339-340.

Goldspink D. F., Kelly F. J., 1984 . Biochem. J., 217, 507-516.

Goldspink D. F., Lewis S. E. M., Kelly F. J., 1984. Biochem. J., 217, 527-534.

McNurlan M. A., Tomkins A. M., Garlick P. J., 1979. Biochem. J., 178, 373-379.

Southon S., Livesey G., Gee J. M., Johnson I. T., 1985. Br. J. Nutr., 53, 87-95. 